\title{
Effect of nitrogen levels and cutting management on growth and yield of multicut forage sorghum [Sorghum bicolor (L.) Moench] variety cofs-29
}

\author{
Shanna A. Crawford*, Jagruti C. Shroff and Shital B. Pargi \\ Department of Agronomy, B. A. College of Agriculture, Anand Agricultural University, \\ ANAND (GUJARAT) INDIA
}

\begin{abstract}
A field experiment was conducted during summer season of 2014 at Anand to study the effect of nitrogen levels and cutting management on multicut forage sorghum [Sorghum bicolor (L.) Moench]. Plant height, number of tillers per metre row, leaf : stem ratio, green forage and dry matter yields was recorded with successive increase in $\mathrm{N}$ levels upto $120 \mathrm{~kg} \mathrm{ha}^{-1}$. The application of $120 \mathrm{~kg} \mathrm{~N} \mathrm{ha}^{-1}$ gave significantly higher growth and yield characters over $60,80,100 \mathrm{~kg} \mathrm{~N} \mathrm{ha}^{-1}$. Statistically highest green forage and dry matter yields were obtained with application of $120 \mathrm{~kg} \mathrm{~N} \mathrm{ha}^{-1}$. Cutting management of first cut at 60 days after sowing and 2 intervals at 50 days produced significantly higher green and dry matter yields as well as growth and yield characters. Based on the findings, nitrogen level of $120 \mathrm{~kg} \mathrm{~N} \mathrm{ha}^{-1}$ and cutting management of first cut at 60 days after sowing +2 subsequent cuts at 50 days interval was found to be the better combination for obtaining higher yields of sorghum under middle Gujarat conditions.
\end{abstract}

Key Words : Cutting management, Green forage, Growth, Nitrogen, Yield

View Point Article : Crawford, Shanna A., Shroff, Jagruti C. and Pargi, Shital B. (2018). Effect of nitrogen levels and cutting management on growth and yield of multicut forage sorghum [Sorghum bicolor (L.) Moench] variety cofs-29. Internat. J. agric. Sci., 14 (1) : 118-122, DOI:10.15740/HAS/IJAS/14.1/118-122.

Article History : Received : 20.05.2017; Revised : 17.11.2017; Accepted : 30.11.2017

\footnotetext{
* Author for correspondence:
} 